\title{
Nitrate sinks and sources as controls of spatio-temporal water quality dynamics in an agricultural headwater catchment
}

\author{
Tobias Schuetz ${ }^{1}$, Chantal Gascuel-Odoux ${ }^{2}$, Patrick Durand ${ }^{2}$, and Markus Weiler ${ }^{1}$ \\ ${ }^{1}$ Chair of Hydrology, University of Freiburg, Freiburg, Germany \\ ${ }^{2}$ INRA, UMR Sol Agro et Hydrosystème Spatialisation, Rennes, France \\ Correspondence to: Tobias Schuetz (tobias.schuetz@hydrology.uni-freiburg.de)
}

Received: 6 August 2015 - Published in Hydrol. Earth Syst. Sci. Discuss.: 31 August 2015

Accepted: 8 January 2016 - Published: 23 February 2016

\begin{abstract}
Several controls are known to affect water quality of stream networks during flow recession periods, such as solute leaching processes, surface water-groundwater interactions as well as biogeochemical in-stream turnover processes. Throughout the stream network, combinations of specific water and solute export rates and local in-stream conditions overlay the biogeochemical signals from upstream sections. Therefore, upstream sections can be considered functional units which could be distinguished and ordered regarding their relative contribution to nutrient dynamics at the catchment outlet. Based on snapshot sampling of flow and nitrate concentrations along the stream in an agricultural headwater during the summer flow recession period, we determined spatial and temporal patterns of water quality for the whole stream. A data-driven, in-stream-mixingand-removal model was developed and applied for analysing the spatio-temporal in-stream retention processes and their effect on the spatio-temporal fluxes of nitrate from subcatchments. Thereby, we have been able to distinguish quantitatively between nitrate sinks, sources per stream reaches, and subcatchments, and thus we could disentangle the overlay of nitrate sink and source signals. For nitrate sources, we determined their permanent and temporal impact on stream water quality and for nitrate sinks, we found increasing nitrate removal efficiencies from upstream to downstream. Our results highlight the importance of distinct nitrate source locations within the watershed for in-stream concentrations and in-stream removal processes, respectively. Thus, our findings contribute to the development of a more dynamic perception of water quality in streams and rivers concerning ecological and sustainable water resource management.
\end{abstract}

\section{Introduction}

Dissolved nutrients, such as nitrate and soluble reactive phosphorus, control surface water trophic status (e.g. Likens and Bormann, 1974). Therefore, increasing concentrations of nitrate in streams and rivers of agricultural landscapes pose a severe risk for their ecological status and drinking water resources downstream. Local nitrate concentrations in streams and rivers depend largely on the following two antagonistic controls: nitrate export processes from landscapes to the stream network (e.g. Carpenter et al., 1998; Lam et al., 2012; Schilling and Zhang, 2004; Tesoriero et al., 2013) and instream removal processes (e.g. Bowes et al., 2014; Burgin and Hamilton, 2007; Covino et al., 2012; Hill, 1996; Montreuil et al., 2010; Mulholland et al., 2008). The stream network itself can be treated as an interface that connects the different landscape components and determines the dynamics of the water quality (Hunsaker and Levine, 1995). Moreover, the convolution of water and matter fluxes from upstream to downstream can be dominated by hydrological turnover processes (i.e. the sum of stream-groundwater exchange fluxes) throughout the stream network (Mallard et al., 2014).

Nitrate export processes comprise various interacting processes and drivers. Depending on present land use (Mulholland et al., 2008) and land management (Basu et al., 2010; Marwick et al., 2014; McCarty et al., 2014), the balance between $\mathrm{N}$ inputs (fertilizers, $\mathrm{N}$ deposition, $\mathrm{N}$ fixation) and $\mathrm{N}$ uptake by plants is the main driver, especially in agricultural landscapes. Organic nitrogen mineralization in soils also plays a major part, in relation to biological activity (Bormann and Likens, 1967), climate (Mitchell et al., 1996), hydrology (Montreuil et al., 2010), and hydrogeolog- 
ical and pedological characteristics of landscapes (Schilling and Zhang, 2004). Another important source for in-stream nitrate is direct nitrification of ammonium in the water column (Bernhardt et al., 2002). Denitrification in anoxic zones, and particularly the riparian zone, acts as an important sink for nitrate (Aquilina et al., 2012; Wriedt et al., 2007). During recession periods (e.g. summer) the connectivity between groundwater $(\mathrm{GW})$ and surface waters plays a key role (Molenat et al., 2008; Smethurst et al., 2014). In agricultural landscapes, this is important due to dense artificial surface and sub-surface drainage networks (Buchanan et al., 2013; Guan et al., 2011; Lam et al., 2012), because they drain superficial $\mathrm{GW}$ which is known to store $\mathrm{N}$ excess from multiple years.

In-stream removal summarizes various processes contributing to a decrease of apparent nitrate concentrations within the stream channel and the adjacent hyporheic zone or stream sediments (Ranalli and Macalady, 2010). The intensity of in-stream removal processes is variable and depends on local conditions and the combination of occurring removal processes. Local streambed morphology determines available mineral and vegetation surfaces for the development of microbial biofilms, which can decrease nitrate concentrations by denitrification processes (Triska et al., 1989). For example, microbial biofilm thickness is an important control for in-stream respiration processes (Haggerty et al., 2014) and thus for denitrification (Burgin and Hamilton, 2007). The impact of photoautotrophic nitrate assimilation depends on incoming solar radiation and occurs mainly during the hours of highest ecosystem productivity (e.g. Fellows et al., 2006; Hall and Tank, 2003). Streambed permeability and the hydraulic conductivity of underlying sediments govern hyporheic exchange fluxes depending on local hydraulic gradients (Krause et al., 2012) and thus largely control denitrification processes (by controlling available nitrate loads) in the anaerobic compartments of the hyporheic zone. There is a large body of literature studying denitrification processes in the hyporheic zone (e.g. Briggs et al., 2013; Harvey et al., 2013; Lewandowski and Nützmann, 2010; Zarnetske et al., 2011, 2012). Without additional information, such as isotopic data, dissolved oxygen concentration dynamics or dissolved organic carbon concentration changes, it is difficult to distinguish biotic and abiotic processes properly. Hence, these processes are summarized as in-stream removal processes, which are either estimated using land use (e.g. Covino et al., 2012), water temperatures (e.g. Lomas and Glibert, 1999), water levels (e.g. Basu et al., 2011; Hensley et al., 2015; Thompson et al., 2011) or discharge (e.g. Flewelling et al., 2014). Compared to hydrological export processes (concentration and dilution processes), in-stream removal processes have a smaller impact on total in-stream nitrate concentrations but they can be responsible for nitrate removal (apparent decrease of nitrate concentrations, excluding dilution processes) in the range of $2-10 \%$ at the reach scale (i.e. 100-200 m) (Harvey et al., 2013; Hensley et al., 2015),
10-30\% for entire river networks (Dupas et al., 2013; Windolf et al., 2011) and up to around $70 \%$ of total exported nitrate-nitrogen at larger scales (i.e. total retention, including retention processes e.g. in the riparian zone or in wetlands) (Dupas et al., 2013; Howarth et al., 1996).

In agricultural landscapes, nitrate export is a type of diffuse pollution even if nitrate fluxes can have distinct locations of inflow into the stream network via subcatchments and related drainage network outlets. Groundwater might enter streams and rivers at spatially distinct locations, due to topography, local heterogeneity of streambeds and hydrogeological settings (Binley et al., 2013; Krause et al., 2012). Hence, changes in total water and nitrate fluxes occur frequently all along the stream network. This is mainly true for first-order stream networks. Considering that a major part of the regional stream and river network consists of first-order streams (e.g. $48 \%$ for the contiguous US; Poff et al., 2006), nitrate export and turnover processes in first-order stream networks can have a large impact on total catchment nitrate export even on larger scales.

In this study, we define the following different subcatchments and stream reaches where nitrate fluxes can vary as nitrate sinks or sources: nitrate sources are tributaries which cause an increase in stream nitrate loads; nitrate sinks are stream sections where nitrate load is decreasing. A nitrate source does not necessarily result in an increase of in-stream nitrate concentration, but does always increase the total nitrate load.

The temporal variations of hydrological and nitrate export processes along different spatial scales have been reproduced by varying modelling approaches (e.g. Donner et al., 2002; Huang et al., 2014; Johnes, 1996; Smethurst et al., 2014; Wagenschein and Rode, 2008; Wriedt and Rode, 2006). Nevertheless, there is still a lack of knowledge on how the spatial patterns of in-stream nitrate concentrations evolve throughout stream networks and whether these patterns are constant over time or vary in time. We analyse this complex interplay of different processes by investigating two main research questions:

1. Can we quantify the spatio-temporal impact of distinct nitrate sinks and sources on nitrate dynamics in a firstorder stream network?

2. Can we determine underlying processes and drivers?

Answering these questions is relevant for a future improvement of water-quality threshold compliances in agricultural landscapes, ecological water quality management e.g. planning of river restoration and the implementation of environmental guidelines, such as the European Water Framework Directive.

In this study, we use a set of discharge and water quality data gathered during 10 snapshot sampling campaigns along the main stream of a small agricultural headwater catchment. A dense artificial drainage network and a predominantly im- 


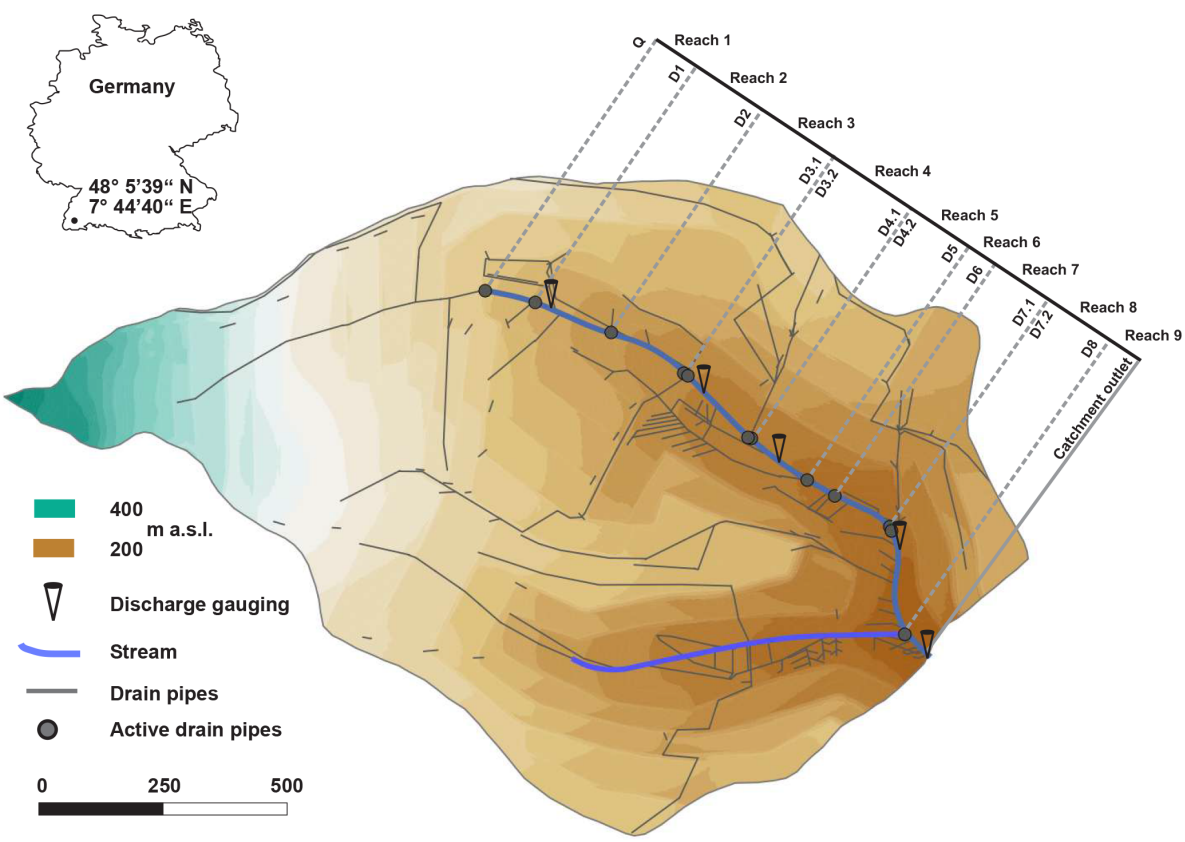

Figure 1. Topographical map of the Löchernbach catchment. The sharp elevation steps in the map represent the vineyard terraces within the catchment. Locations of active drainpipes and stream reaches are marked (dashed lines) with the names referred to throughout the paper.

pervious streambed allowed for detecting distinct groundwater inflow locations. This unique setting allowed us to quantify and model the dynamics of nitrate sinks and sources in a first-order stream network during the summer period. Thus, we can distinguish and quantify the interaction of conservative mixing and dilution processes and biogeochemical instream processes on the (first-order) network scale.

\section{Study area}

The study area is in the Löchernbach catchment, a $1.7 \mathrm{~km}^{2}$ agricultural headwater catchment. It is located in southwestern Germany, within the wine-growing area of the Kaiserstuhl (Fig. 1), with a temperate climate characterized by warm summers and evenly distributed precipitation (Köppen classification: $\mathrm{Cfb}$ ). Mean annual precipitation was $765 \mathrm{~mm}$ between 2008 and 2013 with a mean air temperature of $10.9^{\circ} \mathrm{C}$. Event runoff coefficients vary between 6 and $20 \%$ (e.g. Gassmann et al., 2011; Luft et al., 1985). The dominant soil is a silty calcaric regosol with gleizations in the colluvium (10\% sand, $80 \%$ silt and $10 \%$ clay). The underlying geology is a deep layer of aeolian loess ( $>$ several tens of meters) over Tertiary volcanic basalts. Due to agricultural landscape management in the 1970s, the catchment is divided into an upper area with large artificial terraces covered with vineyards ( $63.2 \%$ of the area) and the main valley where arable crops (e.g. cabbage, corn, beetroots) are dominant $(18.3 \%)$. Other surfaces are paved roads (4.6\%), steep terrace slopes $(10.3 \%)$ and beech forest $(3.5 \%)$ in the upper- most part of the catchment. The catchment's elevation spans from 213 to $378 \mathrm{~m}$ a.s.l. The stream length of the main stream is $1330 \mathrm{~m}$ from the spring ( $256 \mathrm{~m}$ a.s.l.) to the catchment outlet; the main tributary has a length of $600 \mathrm{~m}$ (Fig. 1). The mean streambed slope is $3.2 \%$. A dense sub-surface pipe network (about $9 \mathrm{~km}$ total length) drains the terraces and the fields in the open valley down to the stream. The road drainage system connects to these pipes as well. Considering nonturbulent in-stream conditions during low flow, active drainpipes and mixing lengths in the stream for optimal sampling positions have been determined using handheld thermal imaging (Schuetz and Weiler, 2011). Since the 1970s, we have observed an increase of the unsaturated zone area $(>30 \mathrm{~m})$ in some parts of the catchment and the disconnection of the saturated zone from the stream during summer; that is why, during summer months, base flow is only generated through the artificial drainage system. Clogging effects and artificially fixed stream banks and streambeds cause a predominantly impervious streambed, which causes little streambed infiltration during summer low flows.

\section{Methods}

\subsection{Sampling methods and water quality data}

Sampling campaigns were carried out during base flow periods from June to August 2012. Two types of campaigns were conducted (Table 1). We sampled (a) a $100 \mathrm{~m}$ stream reach (Reach 1, Fig. 1) at five positions during five campaigns for water temperatures $(T)$, electrical conductivity (EC) and 
Table 1. Overview on the measurements and samples obtained during June and August 2012. The number of samples taken at a specific location is given in Arabic numerals. The number of sampling locations is given in Roman numerals.

\begin{tabular}{|c|c|c|c|}
\hline \multirow[t]{2}{*}{ Parameter } & \multirow[t]{2}{*}{ Catchment outlet } & \multicolumn{2}{|c|}{ Snapshot sampling campaigns } \\
\hline & & $\begin{array}{l}\text { Stream network } \\
(1330 \mathrm{~m})\end{array}$ & $\begin{array}{l}\text { Reach No. } 1 \\
(100 \mathrm{~m})\end{array}$ \\
\hline Discharge (salt dilution gauging) & 10 & $10 \times 0$-IV locations & \\
\hline Physical water parameters & 10 & $10 \times$ XXXVI locations & $5 \times \mathrm{V}$ locations \\
\hline Major ions & 2 & $2 \times \mathrm{XXXVI}$ locations & $5 \times \mathrm{V}$ locations \\
\hline Meteorological observations & 10 (Dist. $1.3 \mathrm{~km}$ ) & & \\
\hline Channel geomorphology & & XXIII locations & II locations \\
\hline
\end{tabular}

major anion concentrations (chloride, nitrate, sulfate), and (b) the main stream upstream, downstream and inside all active drainpipes/tributaries (Fig. 1) during 10 campaigns for $T$ and EC, and during 2 campaigns (No. 1, No. 10) for major anion concentrations (chloride, nitrate, sulfate). During each campaign, discharge was determined with salt dilution gauging (slug injection) at the catchment outlet and at several locations (0-4) throughout the stream network (Fig. 1).

For $T$, absolute measurement uncertainty was $0.2 \mathrm{~K}$ and the relative accuracy for EC was $0.5 \%$ of the measurement (WTW LF92). Water samples were taken with $100 \mathrm{~mL}$ brown glass bottles, which were stored in a refrigerator and analysed for major anions (chloride, nitrate, sulfate) within 2 to 4 weeks after sampling with ion chromatography (Dionex DX500). Measurement uncertainty was $0.1 \mathrm{mg} \mathrm{L}^{-1}$ for major anions. Climate data (air temperatures $\left(T_{\text {air }}\right)$, relative humidity, global radiation, wind speed) were taken from a nearby climate station (1.3 km to the south).

Channel geomorphology and streambed structural characteristics, such as channel widths and depths, rock outcrops, and vegetation at the stream banks and in the streambed, were mapped once at 23 random locations distributed throughout the stream network.

\subsection{Stream network discharge patterns}

Patterns of relative stream network discharges are determined by the successive application of mixing equations on EC data (and $T$, chloride or sulfate data at reaches where two active drainpipes were found) obtained upstream, downstream and inside all active drainpipes from the catchment outlet up to the main spring. Fractions $(f)$ of reach drain water discharge $\left(f_{\text {di }}\right)$ relative to downstream stream discharge $\left(Q_{i}\right)$ are calculated after Genereux (1998) based on the conservative mixing equations for two or three endmembers (EC and $T$, or alternatively chloride and sulfate, when available - the majority $(66 \%)$ of the reaches have only one active drainpipe; thus the equations are reduced to two endmembers which can be solved using one parameter only - EC):

$Q_{i}=Q_{\mathrm{di}_{1}}+Q_{\mathrm{di}_{2}}+Q_{i-1}$, $1=f_{\mathrm{di}_{1}}+f_{\mathrm{di}_{2}}+f_{i-1}$,

$\mathrm{EC}_{i}=f_{\mathrm{di}_{1}} \mathrm{EC}_{i_{1}}+f_{\mathrm{di}_{2}} \mathrm{EC}_{\mathrm{di}_{2}}+f_{i-1} \mathrm{EC}_{i-1}$,

and

$T_{i}=f_{\mathrm{di}_{1}} T_{i_{1}}+f_{\mathrm{di}_{2}} T_{\mathrm{di}_{2}}+f_{i-1} T_{i-1}$,

where the subscript $i$ represents the total number of upstream stream reaches (i.e. the number of the actual reach of interest) with $i=0$ at the stream network main source and the subsubscripts 1 and 2 stand for the drainpipes leading to the stream at the upstream end of reach $i$. Resulting fractional drainpipe water contributions are then used to calculate relative discharge patterns throughout the stream network for all sampling campaigns with following equations:

$f_{\text {net,di }}=f_{\text {net }, i} \cdot f_{\text {di }}$

and

$f_{\text {net, }, i-1}=f_{\text {net }, i}-f_{\text {net, } \mathrm{di}_{1}}-f_{\text {net, } \mathrm{di}_{2}}$,

where the subscript "net" stands for fractional water fluxes of all stream reaches (and drainpipes) relative to the discharges at the catchment outlet. This simple conceptual streamsource model was possible due to the disconnection of the saturated zone to the stream, the visual exclusion (thermal imaging (e.g. Schuetz and Weiler, 2011)) of other groundwater sources and the assumption of negligible water losses to the (anthropogenically restructured) colluvium. Absolute stream network discharge patterns and drainpipe discharges are then derived by combining absolute discharge measurements from the catchment outlet $\left(Q_{i=9, \text { obs }}\right)$ with the fractional results of the stream-source model (Eq. 7) for each stream reach $\left(Q_{i}\right)$ and each drainpipe, respectively in the following form:

$Q_{\mathrm{di}}=f_{\text {net }, \mathrm{di}} \cdot Q_{i=9, \mathrm{obs}}$.

Measurement errors and associated uncertainties of calculated stream network discharges and drainpipe discharges are propagated by applying the equations given 
in Genereux (1998) for mixing equations with two and three components, respectively. Stream network discharges $\left(Q_{i, \text { obs }}\right)$ observed with salt dilution gauging (with an approximated error of $10 \%$; e.g. Moore, 2005) are then used to validate derived stream network discharge patterns.

\subsection{Nitrate source concentrations}

Nitrate concentrations measured inside all active drainpipes $\left(C_{\mathrm{di}, \mathrm{obs}}\right)$ during sampling campaigns No. 1 and No. 10 are used to assess nitrate source concentrations for the whole study period: assuming a groundwater system with slow seasonal nitrate dynamics, drainpipe nitrate concentrations for all sampling campaigns (campaigns No. 2 to No. 9) are derived by linearly interpolating between the observed nitrate concentrations from the first and the last sampling campaign (sampling campaigns No. 1 and No. 10). This assumption is in line with observations made in the following summer (results not shown).

\subsection{In-stream nitrate removal}

The sum of all nitrate removal processes in surface waters (i.e. in-stream removal) under stationary conditions regarding discharge input and conservation (i.e. change in concentration equals change in load) is commonly simulated with a kinetic first-order removal model following an exponential function (e.g. Stream Solute Workshop, 1990)

$C_{i, \mathrm{obs}}\left(\tau_{i}\right)=C_{i, \mathrm{obs}}(0) \cdot \exp \left(-k_{i} \tau_{i}\right)$,

where $C_{i, \text { obs }}(0)$ stands for the nitrate concentration observed at the beginning of a stream reach $i$ and $C_{i, \text { obs }}\left(\tau_{i}\right)$ stands for the nitrate concentration observed at the end of stream reach $i . k$ stands for the removal rate $\left(\mathrm{T}^{-1}\right)$ and $\tau$ stands for the stream reach residence time $(T) . \tau$ is determined by

$\tau=\frac{l}{v}$,

where $l$ stands for the reach length (L) and $v$ for the mean flow velocity $\left(\mathrm{L} \mathrm{T}^{-1}\right) . v$ can be approximated with the ratio of discharge to the wetted stream cross section $A\left(\mathrm{~L}^{2}\right)$

$v=\frac{Q}{A}$.

For a trapezoidal stream bed with a known stream bank angle $\alpha\left(^{\circ}\right)$, streambed width $b(\mathrm{~L})$ and mean water depth $h(\mathrm{~L})$, $A$ can be estimated with

$A=b \cdot h+h^{2} \cdot \tan \alpha$.

Combining the Manning-Strickler equation

$v=n^{-1} \cdot R_{\mathrm{hy}}^{2 / 3} \cdot s^{1 / 2}$.

where $n$ stands for Manning's $n\left(\mathrm{~T}^{1 / 3} \mathrm{~L}^{-1}\right), R_{\text {hy }}$ (L) for the hydraulic radius, $s$ stands for the hydraulic gradient (approximated with streambed slope $-\mathrm{LL}^{-1}$ ) with the following assumption after Moore and Anderson (1990):
$R_{\mathrm{hy}}=\xi \cdot A^{1 / 2}$,

where the constant $\xi(-)$ depends on the side-slope ratio of the stream bank and streambed width to depth ratio (Moore and Anderson, 1990) Eqs. (10) to (3) can be transformed into

$h=\frac{b+\left(b^{2}+4 \cdot \tan \alpha\left(\frac{Q \cdot n}{s^{1 / 2} \cdot \xi^{2 / 3}}\right)^{3 / 4}\right)^{1 / 2}}{2 \cdot \tan \alpha}$.

Applying Eqs. (9), (10) and (14) with actual stream reach discharges $\left(Q_{i}\right), \tau$ can be determined individually for each stream reach and discharge.

Empirical nitrate removal rates $k_{i}$ for the five data sets observed at Reach 1 and for the two data sets (campaign No. 1 and No. 10) observed throughout the stream network can then be determined by rearranging Eq. (8) to

$k_{i}=-\frac{\ln \frac{C_{i}\left(\tau_{i}\right)}{C_{i}(0)}}{\tau_{i}}$.

In order to calculate $k_{i}$ for all the sampling campaigns, we try to relate observed $k_{i}$ (for campaigns No. 1 and No. 10 and the five detailed sampling campaigns in Reach 1) with systematically measured parameters. For this, we developed the transfer coefficient $T_{\mathrm{AWET}}\left({ }^{\circ} \mathrm{CL}^{-1}\right.$; air-water-energy transfer)

$T_{\mathrm{AWET}, i}=T_{\text {air }} \frac{\Delta T_{i}}{\left(T_{\mathrm{air}}-T_{i}\right)}$,

which is based on observed mean daytime air temperatures $T_{\text {air }}\left({ }^{\circ} \mathrm{C}\right)$ on the day of each sampling campaign ( 8 a.m. to 8 p.m.), reach-scale stream water heating $\Delta T\left({ }^{\circ} \mathrm{CL}^{-1}\right)$, and the temperature gradient between $T_{\text {air }}$ and stream water temperatures $T_{i}\left({ }^{\circ} \mathrm{C}\right)$. We try to consider the spatial variability of energy inputs into the stream system as a control of biological activity by accounting for the effect of shading (which slows down the increase of $\Delta T$ ) and the effect of local groundwater contributions at the upstream end of a stream reach, which cools down $T_{i}$ and thus increases the gradient between air and water temperatures.

Uncertainties for empirical in-stream nitrate removal rates $k_{i}$ and removal rates estimated with the empirical relationship for $T_{\mathrm{AWET}}$ are done by propagating (Gaussian error propagation) measurement errors and associated uncertainties of observed water and air temperatures and nitrate concentrations.

Standardized comparison of in-stream nitrate removal processes with stream/catchment specific properties is commonly done, following the recommendations of the Stream Solute Workshop (1990), by calculating (among other factors) in-stream uptake rates $k_{\mathrm{C}}$, which equal $k_{i}$ (introduced above), and areal nitrate uptake $U_{i}\left(\mathrm{ML}^{-2} \mathrm{~T}^{-1}\right)$, which is defined by

$U_{i}=C_{i}(0) \cdot h_{i} \cdot k_{i}$. 


\subsection{Implementation of the in-stream-mixing-and-removal model}

Accounting for lateral drainpipe discharges (Sect. 3.2) and stream network discharge patterns, lateral source/drainpipe nitrate concentrations (Sect. 3.3) and in-stream nitrate removal processes (Sect. 3.4), we define a conceptual datadriven in-stream-mixing-and-removal model by combining previous equations as follows:

$C_{i+1}=\frac{C_{i}(0) \cdot \exp \left(-k_{i} \tau_{i}\right) \cdot Q_{i}+C_{\mathrm{di}+1_{1}} \cdot Q_{\mathrm{di}+1_{1}}+C_{\mathrm{di}+1_{2}} \cdot Q_{\mathrm{di}+1_{2}}}{Q_{i+1}}$.

Model application is done by using the measured/estimated $C(0)$ of the uppermost reach, the measured/estimated $C_{d i}$ of the drainpipes, the $Q_{i} / Q_{\mathrm{di}}$ calculated from the endmember mixing and $k_{i}$ estimated with $T_{\mathrm{AWET}}$ as input variables for the successive calculation of stream network nitrate concentrations from upstream to downstream. All parameters, nitrate concentrations and discharges integrated into Eq. (18) are estimated without any calibration. Taking into account that modelling uncertainties will be influenced not only by the uncertainties of $Q_{i}$ (successively estimated from downstream to upstream) and $k_{i}$ estimated with $T_{\mathrm{AWET}}$ but also by the uncertainties implied through the assumptions which were made for the estimations of $\tau_{i}$ and drainpipe nitrate concentrations, the uncertainties in our modelling results will be larger than the differences within our simulations. Hence, we will refrain from an uncertainty analysis of stream network modelling results. However, observed versus predicted comparisons of various parameters quantified the overall error.

\section{Results}

\subsection{Nitrate spatio-temporal patterns on the reach and stream network}

Besides the main spring, we detected, in total, 11 active drainpipes (plus one tributary, Fig. 1) of which 6 were intermittent. At three locations, two pipes drain at one point into the stream. Stream network nitrate concentrations sampled during campaign No. 1 and No. 10 upstream, downstream, and inside all active drainpipes revealed spatial concentration patterns with increasing concentrations from upstream to downstream (Fig. 2) and with different concentration changes among the stream reaches. Nitrate concentrations in the drainpipes differed clearly from in-stream concentrations. In most of the stream reaches, nitrate concentrations decreased, particularly within stream reach No. 1 (Fig. 2, inset), where nitrate was additionally sampled during five snapshot campaigns with a higher spatial resolution.

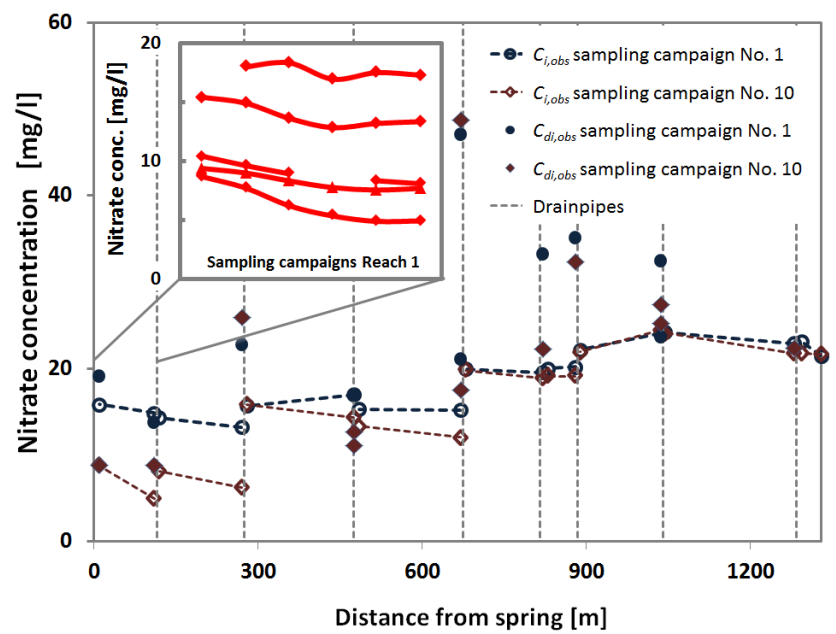

Figure 2. Observed spatio-temporal variations in in-stream and drainpipe nitrate concentrations along the stream network for sampling campaigns No. 1 (27 June 2012) and No. 10 (9 August 2012) and during five sampling campaigns at Reach 1 (inset).

\subsection{Stream network discharge patterns}

We determined all drainpipe discharges for each sampling campaign applying Eqs. (1) to (7) using the obtained EC data (and $T$, chloride or sulfate data, where two drainpipes were located at one position) and the discharges observed at the catchment outlet. Discharge varied among all drainpipes and between all campaigns between 0.05 and $1.7 \mathrm{~L} \mathrm{~s}^{-1}$ with a mean error of $0.21 \mathrm{~L} \mathrm{~s}^{-1}$. While the main spring and drainpipes D1-D6 never contributed more than $0.5 \mathrm{~L} \mathrm{~s}^{-1}$, drainpipes D7.1, D7.2 and D8 delivered most of the time either distinctly more than $0.5 \mathrm{~L} \mathrm{~s}^{-1}$ or remained dry. Using the individual discharge contribution of all drainpipes we determined distinct stream network discharge patterns for each campaign (Fig. 3a and b) with a mean absolute discharge increase of $0.2 \pm 0.06 \mathrm{~L} \mathrm{~s}^{-1} / 100 \mathrm{~m}$ and a mean relative discharge increase of $8 \pm 7 \% / 100 \mathrm{~m}$. Comparing observed discharges with calculated discharges, we find a good agreement with an $R^{2}$ of $0.51(p<0.0001 ; n=24)$ and a mean absolute error of $0.83 \mathrm{~L} \mathrm{~s}^{-1}$ (Fig. 3a, inset). The patterns of relative longitudinal discharge evolution show a clear change between the different sampling campaigns.

Based on a digital elevation model with a spatial resolution of $1 \mathrm{~m}^{2}$ and a vertical resolution of $0.1 \mathrm{~m}$, we determined the mean slopes of the streambed per reach. Mean channel roughness was estimated with a Manning's $n$ of 0.0585 $\left(s^{1 / 3 / m}\right)$ for the total stream network, following the procedure described in Schneider and Arcement (1989). Stream bank angles were uniformly approximated with $30^{\circ}$ and mean streambed width was set to $0.38 \mathrm{~m}$, based on the observed mean streambed width obtained during a random sampling of stream morphology (the channel was restructured in the 1970s, and is very homogenously shaped). By applying 
Table 2. Overview on stream reach residence times $\tau$ and stream reach specific parameters applied in Eqs. (9) to (12).

\begin{tabular}{|c|c|c|c|c|c|c|c|c|}
\hline $\begin{array}{l}\text { Reach } \\
\text { No. }\end{array}$ & $\begin{array}{r}\text { Reach } \\
\text { length } \\
{[\mathrm{m}]}\end{array}$ & 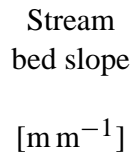 & $\begin{array}{c}\text { Mean } \\
\text { discharge } \\
{\left[\mathrm{Ls}^{-1}\right]}\end{array}$ & $\begin{array}{c}\text { Max. } \\
\text { discharge } \\
{\left[\mathrm{Ls}^{-1}\right]}\end{array}$ & $\begin{array}{l}\text { Min. } \\
\text { discharge } \\
{\left[\mathrm{Ls}^{-1}\right]}\end{array}$ & $\begin{array}{r}\text { Mean } \\
\text { residence } \\
\text { time } \\
{[\mathrm{s}]}\end{array}$ & $\begin{array}{l}\text { Min. } \\
\text { residence } \\
\text { time } \\
{[\mathrm{s}]}\end{array}$ & $\begin{array}{r}\text { Max. } \\
\text { residence } \\
\text { time } \\
{[\mathrm{s}]}\end{array}$ \\
\hline 1 & 100 & 0.075 & 0.2 & 0.5 & 0.02 & 642 & 441 & 1092 \\
\hline 2 & 150 & 0.052 & 0.5 & 1.1 & 0.1 & 836 & 640 & 1184 \\
\hline 3 & 195 & 0.039 & 0.8 & 1.5 & 0.2 & 1068 & 854 & 1517 \\
\hline 4 & 185 & 0.022 & 1.1 & 1.9 & 0.2 & 1133 & 937 & 1583 \\
\hline 5 & 140 & 0.019 & 1.5 & 2.4 & 0.4 & 820 & 704 & 1138 \\
\hline 6 & 50 & 0.023 & 1.6 & 2.4 & 0.4 & 267 & 234 & 358 \\
\hline 7 & 145 & 0.014 & 2.0 & 3.0 & 0.6 & 877 & 772 & 1178 \\
\hline 8 & 235 & 0.019 & 2.4 & 5.2 & 1.1 & 1211 & 969 & 1428 \\
\hline 9 & 35 & 0.021 & 3.1 & 5.2 & 1.7 & 163 & 140 & 188 \\
\hline
\end{tabular}

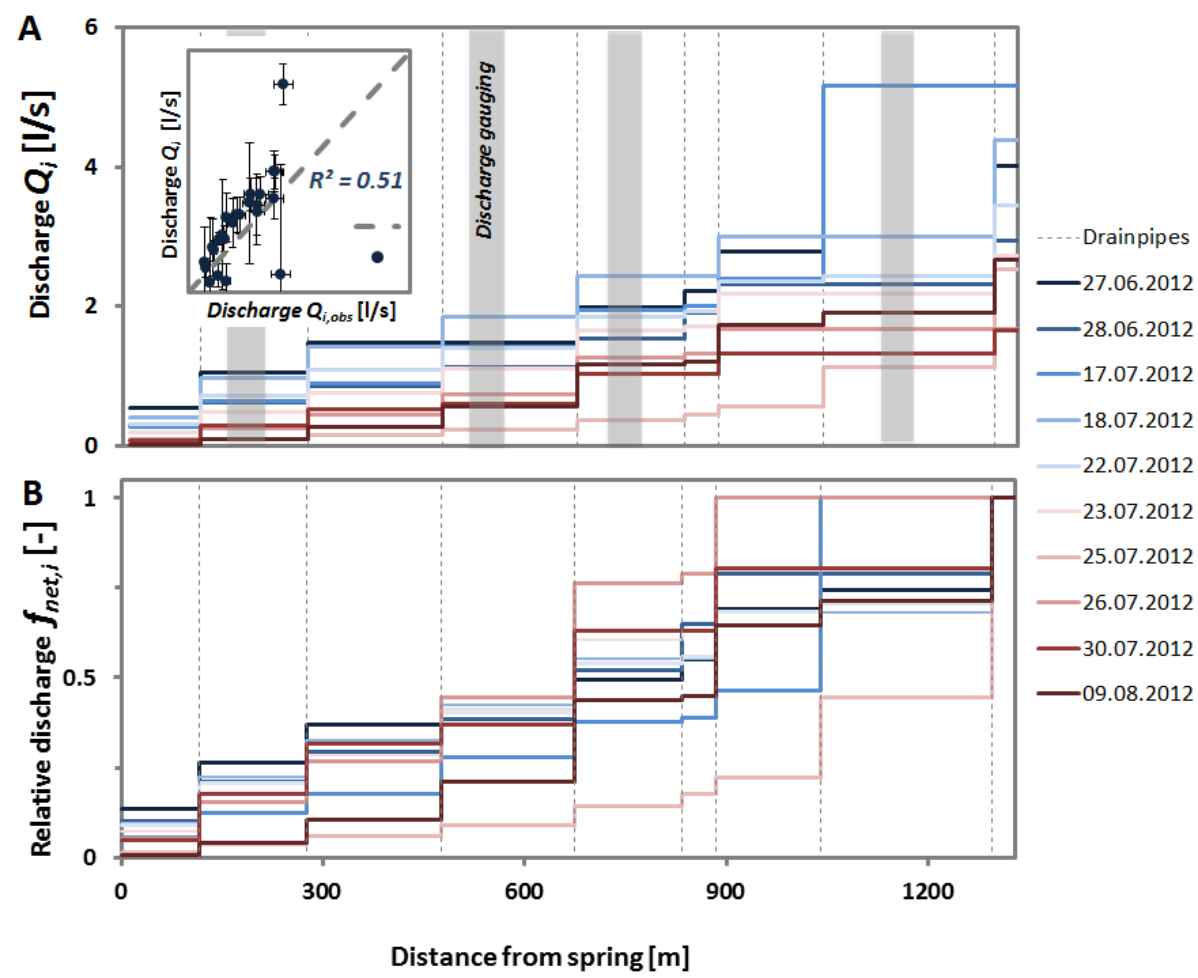

Figure 3. (a) Simulated stream network discharge patterns $Q_{i}$ for all days. Inset in (a): comparison of calculated $\left(Q_{i}\right)$ and measured discharges $\left(Q_{i, \text { obs }}\right)$. (b) Calculated patterns of relative discharges $f_{\text {net }, i}$ for all days. Sampling campaigns No. 1-No. 10 are colour-coded from blue to red. Dashed lines $(\mathbf{a}, \mathbf{b})$ symbolize the positions of the drainpipes. Shaded bars (a) represent the locations of salt dilution gauging.

Eqs. (9) to (14), the residence times of each stream reach was derived, which varied between 234 and $1583 \mathrm{~s}$. Variations of residence times between the reaches and the different campaigns depend only on the differences of reach lengths, streambed slopes and actual discharge (Table 2).

\subsection{Nitrate dynamics along the stream network}

Nitrate concentrations in the drainpipes ranged between 8.7 and $48 \mathrm{mg} \mathrm{L}^{-1}$ with a mean increase of $1.3 \mathrm{mg} \mathrm{L}^{-1} / 100 \mathrm{~m}$ from upstream to downstream $\left(R^{2}=0.21 ; p<0.05 ; n=24\right)$. Between campaign No. 1 and No. 10, eight drainpipes showed decreasing concentrations with a mean decrease of $5.2 \pm 2.7 \mathrm{mg} \mathrm{L}^{-1}$ and four drainpipes showed increasing concentrations with a mean increase of $2.3 \pm 0.9 \mathrm{mg} \mathrm{L}^{-1}$. 

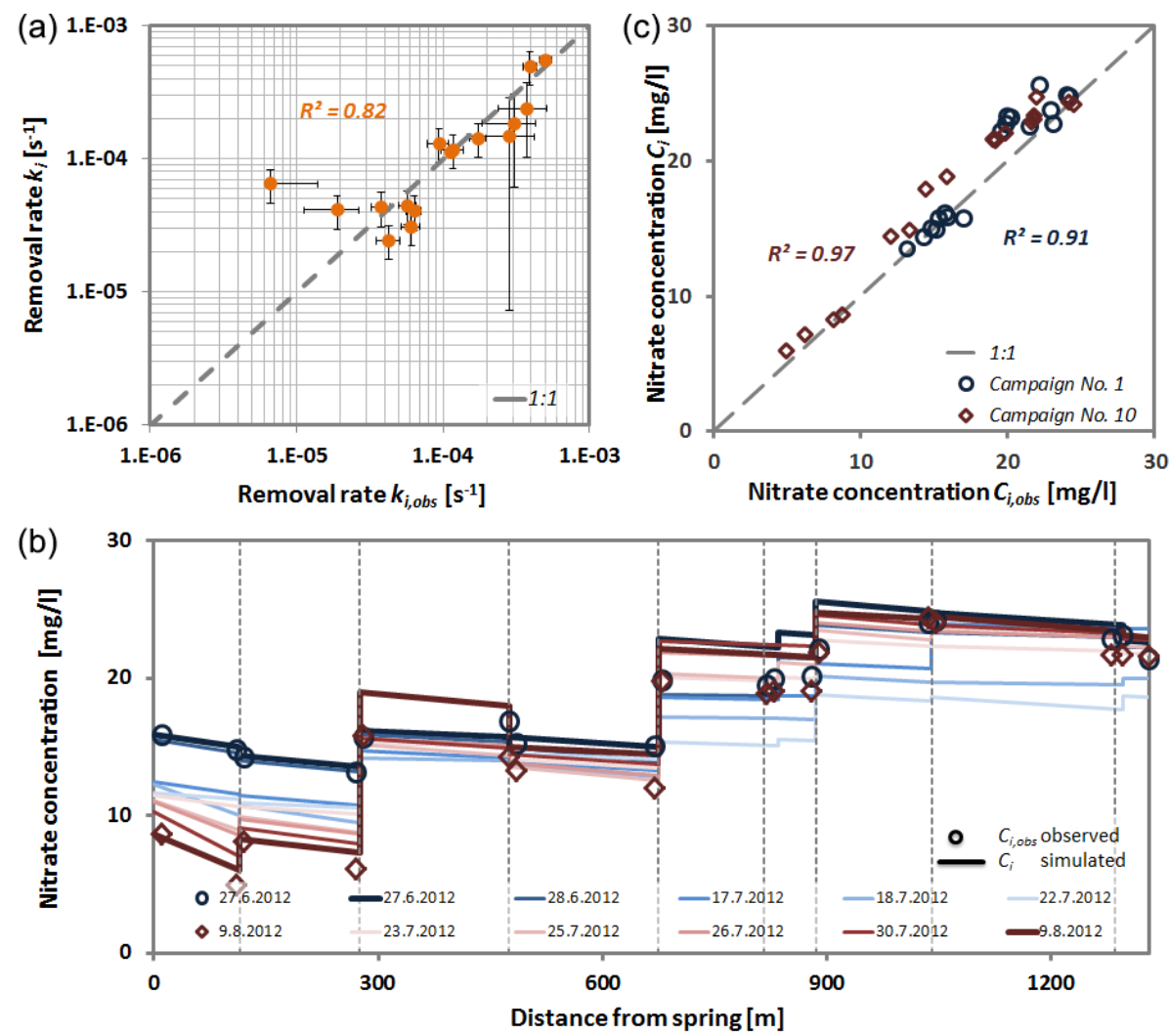

Figure 4. (a) Estimated $\left(k_{i}\right)$ and empirical $\left(k_{i, \text { obs }}\right)$ in-stream nitrate removal rates. (b) Observed $\left(C_{i, \text { obs }}\right.$ symbols $)$ and calculated $\left(C_{i}\right.$ lines $)$ in-stream nitrate concentration patterns for all days. Sampling campaigns No. 1-No. 10 are colour-coded from blue to red. Dashed lines symbolize the positions of the drainpipes. (c) Comparison of modelled and observed in-stream nitrate concentrations for campaigns No. 1 (blue circles) and No. 10 (red diamonds).

By applying Eq. (15) to the observed in-stream nitrate concentration changes within the reaches, the empirical in-stream nitrate removal rate $k_{i}$ was calculated, and varies between $3.5 \times 10^{-6}$ and $5 \times 10^{-4} \mathrm{~s}^{-1}$. Relating the empirical nitrate removal rate $k_{i}$ to the conceptual transfer coefficient $T_{\text {AWET }}$ shows a significant linear correlation $\left(R^{2}=0.82 ; p<0.0001 ; n=21\right)$. In order to avoid the prediction of negative removal rates, the log-transform of $k_{i}$ is tested against $T_{\text {AWET }}$. This yields a linear correlation with lower statistical power $\left(R^{2}=0.63 ; p=0.0002 ; n=16\right)$. Comparing the resulting regression model with empirical instream nitrate removal rates, we find a good approximation with a mean relative error of $40 \%$, which seems to be appropriate, though deviations between empirical and estimated removal rates increase only when the observed removal rates become very small (Fig. 4a).

Applying the in-stream-mixing-and-removal model (Eq. 18) to all stream network data sets (spatially discretized drainpipe discharges and nitrate loads) we find distinct patterns of nitrate concentrations along the stream network (Fig. 4b). Stream nitrate concentration patterns show that the impact of nitrate sources regarding the downstream changes of in-stream nitrate concentrations is directly connected with interaction between local source fluxes and in-stream nitrate and water fluxes. The temporal variability of removal processes simulated for different stream reaches is clearly changing the picture. Some of the nitrate sources and stream reaches show a distinctly stronger impact on the temporal and spatial evolution of in-stream nitrate concentrations than others. The simulation results were tested against in-stream nitrate concentrations observed during sampling campaigns No. 1 and No. 10 (Fig. 4b (blue and red lines/symbols) and Fig. 4c). With an $R^{2}$ of 0.91 for sampling campaign No. 1 and an $R^{2}$ of 0.97 for sampling campaign No. 10 (Fig. 4c) the observations are reproduced quite well. This includes the following temporal changes of in-stream nitrate concentrations: at the beginning of the study (sampling campaign No. 1) in-stream nitrate concentrations were generally less variable throughout the stream network than at the end of the study (sampling campaign No. 10), when very low concentrations occurred as well.

\subsection{Hierarchy of nitrate sinks and sources}

The effects of nitrate sinks and sources on in-stream nitrate dynamics are visualized considering the spatial and tempo- 


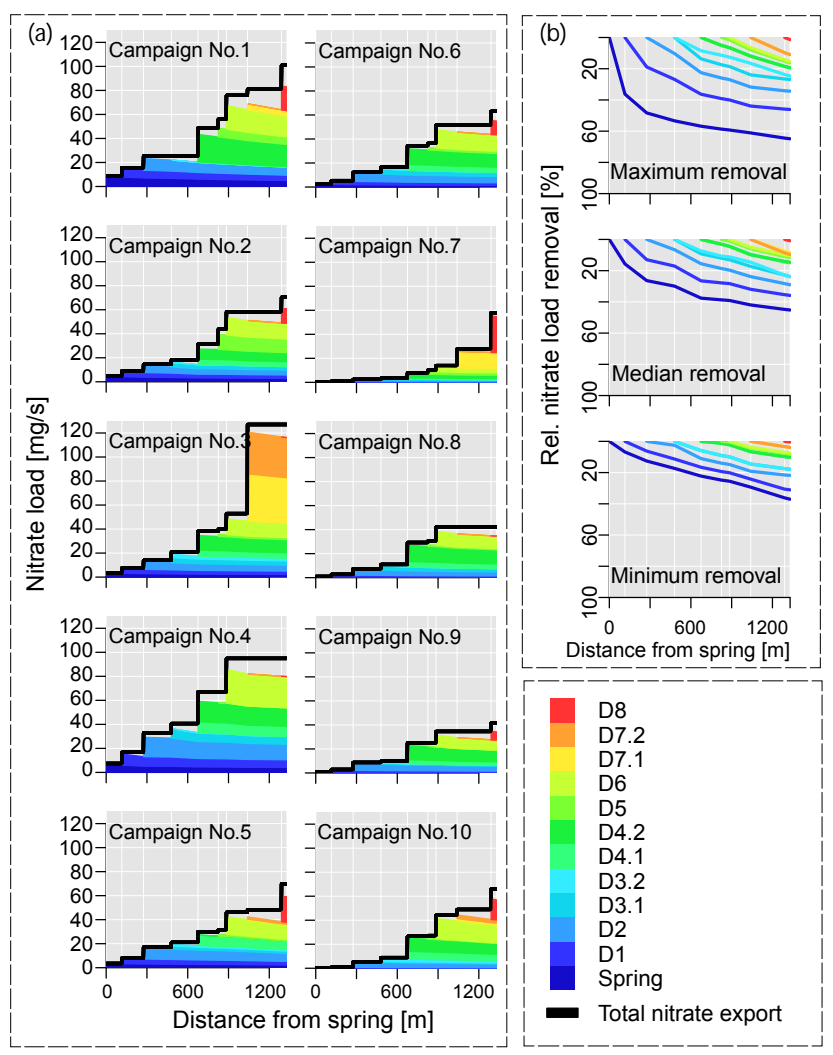

Figure 5. (a) In-stream nitrate loads per source for all days (the black line presents cumulative nitrate load emissions without instream removal). (b) Maximum, median and minimum in-stream nitrate load removal per source relative $(\%)$ to the total emitted nitrate load.

ral distribution of nitrate loads throughout the stream network (Fig. 5a). For each sampling campaign distinct nitrate load distributions and contributions were found. The detailed spatial representation of nitrate sinks and sources in Fig. 5 shows that absolute and relative impacts of distinct sinks and sources on total nitrate load at the catchment outlet are more pronounced than the variations of nitrate concentration (Fig. 4b) and discharge dynamics (Fig. 3a). Median relative nitrate removal per source (i.e. the magnitude of in-stream removal per source at the catchment outlet, Fig. 5b) clearly depends on the position of a source in the stream network $\left(R^{2}=0.95 ; p<0.0001 ; n=12\right)$. Nitrate loads emitted at the catchment spring are removed between 20 and $50 \%$, while loads emitted in the lower sections of the stream network show a much lower relative removal. In contrary, the differences of relative nitrate load removal per source between adjacent nitrate sources are not related to the specific reach lengths.

Among the different nitrate sources, we have found a distinct hierarchy (Fig. 6a), which is more controlled by drainpipe discharge (median nitrate load vs. drainpipe discharge: $\left.R^{2}=0.85 ; p<0.0001 ; n=120\right)$ than by nitrate concentra-

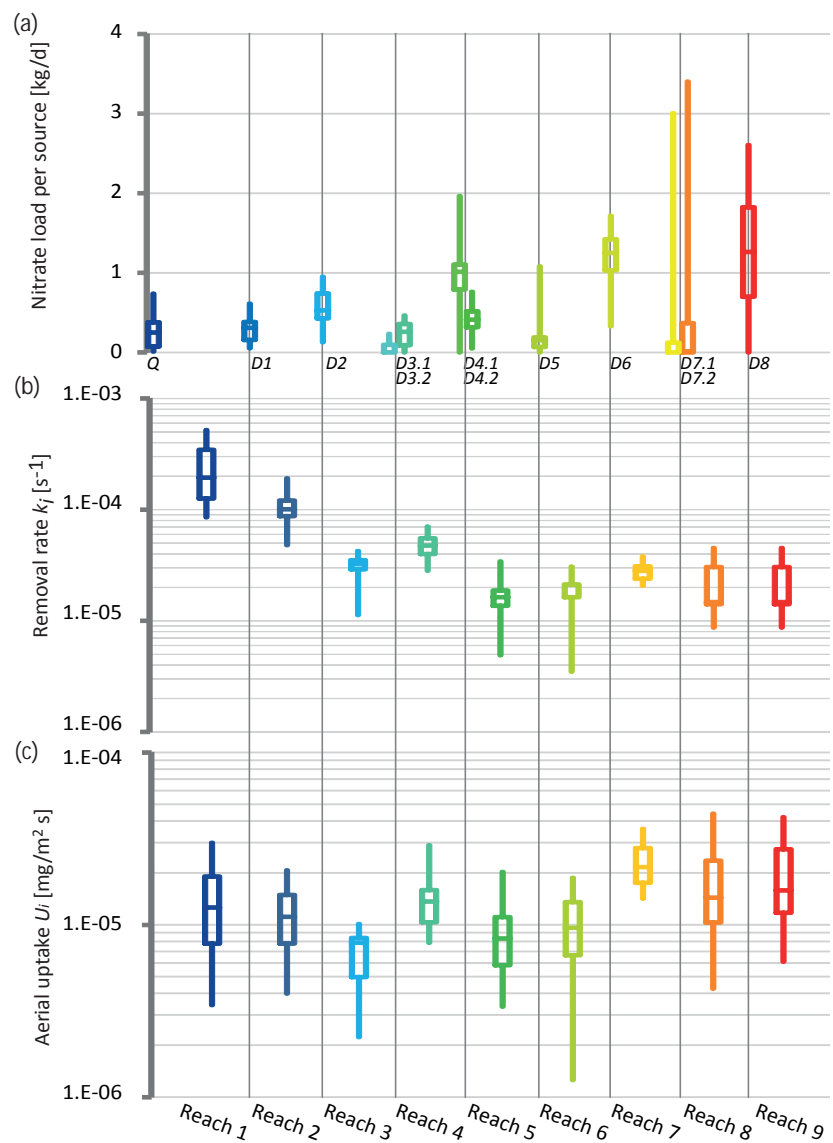

Figure 6. (a) Hierarchy and range of nitrate loads per source ranked by their median nitrate load emission. (b) Hierarchy and range of in-stream nitrate removal rates $k_{i}$ per reach sorted from upstream to downstream. (c) Range of areal uptake rates $U_{i}$ per reach sorted from upstream to downstream. Boxplots present the $0.01,0.25,0.5$, 0.75 and 0.99 quantiles of each measure.

tions (no significant correlation between median nitrate loads and drainpipe nitrate concentrations). During most of the days, some sources contribute the major part of total nitrate loads (D8, D6, D4.1) while other sources vary between major nitrate load contributions and no contributions at all (i.e. intermittent drainpipes, e.g. D7.1, D7.2). Positioning along the stream shows no correlation with the rank of the source contribution.

When comparing the rankings of median in-stream nitrate removal $k_{i}$ (Fig. 6b) and median areal nitrate uptake rates $U_{i}$ (Fig. 6c), we find a different order of stream reaches: while in-stream nitrate removal rates decrease from upstream to downstream $\left(R^{2}=0.74 ; p=0.0029 ; n=9\right)$, the areal nitrate uptake rates $U_{i}$ do not show such a clear pattern. In the downstream reaches (Reach 7, 8, and 9) areal uptake rates are the highest but there is no significant relation within the ranking of areal nitrate uptake $U_{i}$ and the spatial location along the stream network. 

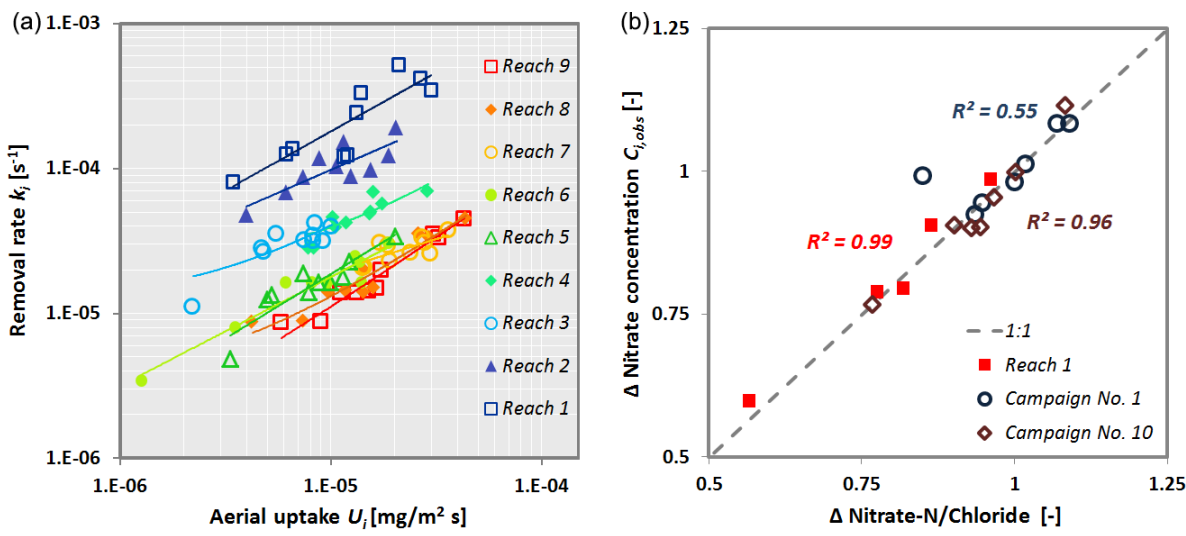

Figure 7. (a) Comparison of estimated in-stream nitrate removal rates $k_{i}(\mathrm{~s}-1)$ and areal nitrate uptake rates $U_{i}\left(\mathrm{mg} \mathrm{m}^{2} \mathrm{~s}\right)$ per stream reach. (b) Comparison of observed relative changes in nitrate concentrations with observed relative changes in the ratio of nitrate/chloride per stream reach observed during the sampling campaigns No. 1 and No. 10 and during the additional sampling campaigns at Reach 1.

\section{Discussion}

We have quantified nitrate sinks and sources, which contribute to the spatial patterns of in-stream nitrate concentrations along a first-order stream network and their evolution in time. We are able to show how distinct nitrate sinks and sources persistently dominate these patterns over time. These findings are supported by several recent studies which show the uniqueness of spatial water quality composition for larger scales based on stream sampling campaigns (e.g. Lam et al., 2012; Vogt et al., 2015) or based on modelling approaches describing the spatial distribution of nitrate export in stream networks (e.g. Isaak et al., 2014). Both approaches show the importance of spatial "hot spots" regarding nitrate sources. The originality of our work, in comparison to these studies, is that we have studied the temporal variations of nitrate contributions, with an emphasis on local flux contributions, based on a data-driven modelling approach.

\subsection{Nitrate sources}

The unique setting in our study area (known locations of groundwater inflow and negligible stream water losses) allowed us to infer water and nitrate fluxes and flux changes along the stream without neglecting important contributions. Looking at the longitudinal stream profiles of absolute and relative discharges (Fig. 3a and b) we find a high temporal variability within the spatial patterns of the catchment drainage system. This can be explained by specific discharge recessions for different landscape elements/hydrogeological storages during baseflow periods (Payn et al., 2012). The different subcatchments (or rather the areas connected to the drainpipes) show differences regarding their spatial extent, elevations and land use combinations. This high variability was not expected before, though Mallard et al. (2014) show that characteristic longitudinal stream discharge profiles can be found for specific catchments (e.g. with a certain shape and channel network). For the observed time period, our data show that these patterns are rather unstable. Consequently, the impact of certain subcatchments on total nitrate export changes over time and the spatial changes can be more or less dominant.

\subsection{Nitrate sinks}

In this study, stream network nitrate sinks are defined as the sum of all in-stream nitrate removal processes on each reach. We do not use the presented approach to distinguish between different biogeochemical processes but to empirically simulate the net effect of biogeochemical processes on downstream nitrate concentrations. For other catchments, additional nitrate mass losses along the stream channel (i.e. indirect groundwater recharge) have to be considered. Mallard et al. (2014) showed that cumulative gross channel discharge losses could retain large parts of the discharges generated in the headwaters (and thus large parts of the nitrate loads emitted from the headwaters). Depending on the spatial differences in groundwater nitrate concentrations, the hydrological turnover could then partly overlay the processes described in this study. However, the hydrological turnover will similarly influence downstream groundwater nitrate concentrations and thus the magnitude of downstream nitrate sources.

We estimated in-stream nitrate removal rates $k_{i}$ using the empirical transfer coefficient $T_{\mathrm{AWET}}$, which describes the energy limitation of a specific stream reach. Comparing the ranking of in-stream nitrate removal rates $k_{i}$ and areal uptake rates $U_{i}$ (Fig. 7a), we find an increasing uptake efficiency (i.e. lower removal rates causing equal areal uptake) from upstream to downstream. Considering that for a given reach, $U_{i}$ and $k_{i}$ are linked by stream reach water levels and nitrate concentrations (Eq. 17), we can conclude that the increase in uptake efficiency can be likewise caused by increasing water levels or nitrate concentrations. Nonetheless, observable 
changes in in-stream nitrate concentrations are larger in upstream reaches than in the downstream reaches.

However, on smaller scales (such as the study area) the temporal variability of in-stream nitrate concentrations cannot be explained by land use alone (e.g. Mulholland et al., 2008; Ruiz et al., 2002). A higher spatial resolution of geomorphic or physicochemical information is needed. Although we know that gross primary production and in-stream nitrate turnover in stream ecosystems is directly linked to water temperatures and incoming radiation (e.g. Fellows et al., 2006; Hall and Tank, 2003; Lomas and Glibert, 1999), the high spatial resolution of our study did not allow a direct comparison of observed in-stream nitrate removal to atmospheric conditions. We found a significant correlation for $T_{i}$ and empirical removal rates $k_{i}$ on the reach scale (Reach 1), which was not valid on the network scale. This can be explained by the spatial variability of inflowing groundwater/nitrate sources, channel geomorphology or vegetation density. Hence, we explicitly consider the impacts of local shading, upstream stream water temperatures (which are a measure of surface travel time) and local cooling effects of inflowing groundwater for the derivation of $T_{\text {AWET }}$. A more physically based interpretation of the involved processes would have required deeper knowledge on the spatial distribution of streambed geomorphology and vegetation. In many other studies (e.g. Alexander et al., 2009; Basu et al., 2011; Hensley et al., 2015) water levels alone were used for the estimation of in-stream removal processes. Though existing hydraulic information is commonly used to estimate both, stream reach residence times (Stream Solute Workshop, 1990) and areal nitrate uptake rates $U_{i}$ (Eq. 14), we think that the independent estimation of $k_{i}$, by using additional measurements of stream water temperatures, groundwater temperatures and air temperatures, improves the reliability of the presented non-calibrated and data-driven modelling approach. Nonetheless, one must consider that hyporheic exchange processes (and thus denitrification by heterotrophic organisms) contribute to nitrate removal processes as well (Harvey et al., 2013; Kiel and Cardenas, 2014; Zarnetske et al., 2011). Hence, the interdependency of hydraulic conditions and energy availability at the reach scale cannot be easily resolved. For the present study, we could show that the change in nitrate concentrations per reach relates almost $1: 1$ to the change in nitrate-N/chloride ratios per reach for all our observations (Fig. 7b). This is also true for the three observations where an increase in nitrate concentrations occurred from upstream to downstream. Nitrate-N to chloride mass ratios has been previously used to indicate that other processes, such as dilution (Schilling et al., 2006) or rather denitrification (Tesoriero et al., 2013), are responsible for the change in nitrate concentrations. Hence, we conclude that both controls are relevant for a specific stream network and thus the decision to use one measurement or the other should be made with great care.

\subsection{Hierarchy of nitrate sinks and sources}

Considering the relationship of in-stream water fluxes and nitrate concentrations with water and nitrate flux contributions from landscape units along the stream network, in-stream nitrate concentrations can change clearly from upstream to downstream through enrichment and dilution processes. The effect of the spatial arrangement of nitrate source areas and stream reaches along the stream network with high or low retention potential is manifested in the longitudinal nitrate concentration patterns observable along a stream or river (e.g. Figs. 2 and 4a). It becomes clear that there is a direct impact of the location of a tributary, or a groundwater source of nitrate and stream reaches with high nitrate turnover rates, on downstream nitrate concentrations. Nitrate loads emitted by specific upstream sources can be removed to a large extent on their way through a stream network (Fig. 5).

The seasonal variations of in-stream nitrate concentrations could be larger than the variations of nitrate concentrations presented within this study. Nevertheless, these variations occur during relatively short time periods (summer low flows) when ecological in-stream conditions are crucial for in-stream habitat conditions, e.g. a nutrient surplus in combination with warm temperatures and high solar radiation input can cause eutrophic conditions in the stream ecosystem. Hence, a better understanding of the evolution of apparent in-stream nitrate concentrations is relevant e.g. for water quality threshold exceedances. Due to the stationary or slowly changing conditions during low flow periods, spatial water quality patterns are little affected by hydrodynamic and geomorphic dispersion of point source/subcatchment nitrate emissions (Botter and Rinaldo, 2003). Hence, observed step changes of in-stream concentrations can be expected as a frequently occurring phenomenon. In many studies published on nitrate export, the focus is on nitrate concentrations observed at a single location in the stream (i.e. catchment outlet). Our results (specifically Figs. 2b and 4b) illustrate that there is a clear need to better understand the spatiotemporal hydrological connectivity (and thus water and matter fluxes) of landscapes to the fluvial systems. For the instream-mixing-and-removal model, applied to the Löchernbach catchment, distinct boundary conditions could be defined. In other systems, where export processes to the stream occur more diffusely and where non-negligible stream water losses occur (i.e. groundwater-surface water interaction), an improved understanding of nitrate sinks and sources is even more important. For these systems, we have to additionally consider the variable interplay of local gradients between groundwater and surface water (Krause et al., 2012) and their influence on water and matter turnover processes in the stream network and the reverse effect of in-streammixing-and-removal processes on local groundwater quality dynamics. The study of Mallard et al. (2014) provided a first step into a longitudinally more dynamic system understanding of water flux dynamics (and thus water quality dynam- 
ics) in stream and river networks. We could show that for biogeochemically active substances, such as nutrients, their approach should be supplemented by the consideration of instream cycling and retention processes and their masking effects from upstream to downstream.

Our results apply mostly to first-order stream networks. However, due to the large effects on first-order catchment nitrate export and the dominance of first-order catchments in the regional river network (Poff et al., 2006) our results are relevant even on larger scales: our findings imply that a more complex understanding of the hydro-ecological functioning of a specific stream or river system, regarding the origin of water and of matter fluxes, has to be applied for the planning of ecological measures or sustainable water resource management. This concerns the distribution of different types of land use within the catchment (e.g. intensive agriculture) as well as their hydrological connectivity to the stream network. For example, when planning river restorations, we have to recognize that e.g. the combination of high soil nitrate concentrations and a shallow tile drain system may lead to increased export rates for a specific subcatchment. For such a case the downstream implementation of a restored river corridor could then have an enhanced impact as a nitrate sink (compare e.g. Bukaveckas, 2007). In contrast, in densely populated countries, as in the midwestern part of Europe, the implementation of e.g. river restoration measures is usually done in places where property rights (and legal terms) allow the implementation of these measures. Furthermore, the integral impact of local ecological in-stream measures on downstream nitrate concentration patterns, which are more relevant for water quality threshold compliances than nitrate loads, should be considered as well. This might even be economically useful in river systems with downstream drinking water production plants and occurring stream bank filtration processes. Moreover, the planning and operation of water quality monitoring networks could be improved by regarding the spatial and temporal covering of important nutrient sinks and sources.

\section{Conclusions}

Summarizing the findings of this study, we can show that the effect of nitrate sinks and sources on stream network water quality, its dynamics, and total catchment nitrate export can be quantified and ordered regarding their impact along the stream. On the scale of a first-order stream network, we could directly derive the impact of specific nitrate sinks and sources on downstream water quality variations. In accordance with other studies, we find that spatially distinct nitrate sources can dominate catchment nitrate export and "hot spots" of in-stream nitrate removal can be found at the reach scale. Moreover, the specific boundary conditions of the study area allowed to fully distinguish between mixing and dilution processes and biogeochemical in-stream removal processes along the first-order stream network. Simulating in-stream nitrate removal by applying a novel transfer coefficient based on energy availability, we also show that $\mathrm{N}$ cycling in agricultural headwater streams can be predicted by sources other than hydraulic information. Contributing to the actual discussion in stream ecohydrology, our findings highlight the relevance of first-order stream networks even for larger scales and they imply that a more dynamic anticipation of water quality from upstream to downstream has to be considered for the setup of ecohydrological studies as well as for the implementation of ecological measures and stream or river restoration.

Acknowledgements. We would like to thank Manuel Saroos for his efforts during the sampling campaigns, Till Volkmann for the climate data and Barbara Herbstritt for her help in the lab. The article processing charge was funded by the German Research Foundation (DFG) and the Albert Ludwigs University Freiburg in the funding programme Open Access Publishing.

Edited by: A. D. Reeves

\section{References}

Alexander, R. B., Böhlke, J. K., Boyer, E. W., David, M. B., Harvey, J. W., Mulholland, P. J., Seitzinger, S. P., Tobias, C. R., Tonitto, C., and Wollheim, W. M.: Dynamic modeling of nitrogen losses in river networks unravels the coupled effects of hydrological and biogeochemical processes, Biogeochemistry, 93, 91-116, doi:10.1007/s10533-008-9274-8, 2009.

Aquilina, L., Vergnaud-Ayraud, V., Labasque, T., Bour, O., Molénat, J., Ruiz, L., de Montety, V., De Ridder, J., Roques, C., and Longuevergne, L.: Nitrate dynamics in agricultural catchments deduced from groundwater dating and long-term nitrate monitoring in surface and groundwaters, Sci. Total Environ., 435-436, 167-178, doi:10.1016/j.scitotenv.2012.06.028, 2012.

Basu, N. B., Destouni, G., Jawitz, J. W., Thompson, S. E., Loukinova, N. V, Darracq, A., Zanardo, S., Yaeger, M., Sivapalan, M., Rinaldo, A., and Rao, P. S. C.: Nutrient loads exported from managed catchments reveal emergent biogeochemical stationarity, Geophys. Res. Lett., 37, L23404, doi:10.1029/2010g1045168, 2010.

Basu, N. B., Rao, P. S. C., Thompson, S. E., Loukinova, N. V., Donner, S. D., Ye, S., and Sivapalan, M.: Spatiotemporal averaging of in-stream solute removal dynamics, Water Resour. Res., 47, W00J06, doi:10.1029/2010wr010196, 2011.

Bernhardt, E. S., Hall Jr., R. O., and Likens, G. E.: Wholesystem estimates of nitrification and nitrate uptake in streams of the Hubbard Brook Exp. Forest. Ecosyst., 5, 419-430, doi:10.1007/s10021-002-0179-4, 2002.

Binley, A., Ullah, S., Heathwaite, A. L., Heppell, C., Byrne, P., Lansdown, K., Trimmer, M., and Zhang, H.: Revealing the spatial variability of water fluxes at the groundwatersurface water interface, Water Resour. Res., 49, 3978-3992, doi:10.1002/wrcr.20214, 2013. 
Bormann, F. and Likens, G.: Nutrient cycling, Science, available at: http://biology.duke.edu/upe302/pdffiles/Emily_ BormannLikens1967.pdf (last access: 22 May 2014), 1967.

Botter, G. and Rinaldo, A.: Scale effect on geomorphologic and kinematic dispersion, Water Resour. Res., 39, 1286, doi:10.1029/2003WR002154, 2003.

Bowes, M. J., Jarvie, H. P., Naden, P. S., Old, G. H., Scarlett, P. M., Roberts, C., Armstrong, L. K., Harman, S. A., Wickham, H. D., and Collins, A. L.: Identifying priorities for nutrient mitigation using river concentration-flow relationships: the Thames basin, UK, J. Hydrol., 517, 1-12, doi:10.1016/j.jhydrol.2014.03.063, 2014.

Briggs, M. A., Lautz, L. K., and Hare, D. K.: Residence time control on hot moments of net nitrate production and uptake in the hyporheic zone, Hydrol. Process., 28.11, 3741-3751, doi:10.1002/hyp.9921, 2013.

Buchanan, B., Easton, Z. M., Schneider, R. L., and Walter, M. T.: Modeling the hydrologic effects of roadside ditch networks on receiving waters, J. Hydrol., 486, 293-305, doi:10.1016/j.jhydrol.2013.01.040, 2013.

Bukaveckas, P. A.: Effects of channel restoration on water velocity, transient storage, and nutrient uptake in a channelized stream, Environ. Sci. Technol., 41, 1570-1576, doi:10.1021/es061618x, 2007.

Burgin, A. J. and Hamilton, S. K.: Have we overemphasized the role of denitrification in aquatic ecosystems? A review of nitrate removal pathways, Front. Ecol. Environ., 5, 89-96, 2007.

Carpenter, S. R., Caraco, N. F., Correll, D. L., Howarth, R. W., Sharpley, A. N., and Smith, V. H.: Nonpoint pollution of surface waters with phosphorus and nitrogen, Ecol. Appl., 8, 559-568, 1998.

Covino, T., McGlynn, B., and McNamara, R.: Land use/land cover and scale influences on in-stream nitrogen uptake kinetics, J. Geophys. Res.-Biogeo., 117, G02006, doi:10.1029/2011jg001874, 2012.

Donner, S. D., Coe, M. T., Lenters, J. D., Twine, T. E., and Foley, J. A.: Modeling the impact of hydrological changes on nitrate transport in the Mississippi River Basin from 1955 to 1994, Global Biogeochem. Cy, 16, 16-1-16-19, doi:10.1029/2001GB001396, 2002.

Dupas, R., Curie, F., Gascuel-Odoux, C., Moatar, F., Delmas, M., Parnaudeau, V., and Durand, P.: Assessing $\mathrm{N}$ emissions in surface water at the national level: comparison of country-wide vs. regionalized models, Sci. Total Environ., 443, 152-162, doi:10.1016/j.scitotenv.2012.10.011, 2013.

Fellows, C. S., Valett, H. M., Dahm, C. N., Mulholland, P. J., and Thomas, S. A.: Coupling Nutrient Uptake and Energy Flow in Headwater Streams, Ecosystems, 9, 788-804, doi:10.1007/s10021-006-0005-5, 2006.

Flewelling, S. A., Hornberger, G. M., Herman, J. S., Mills, A. L., and Robertson, W. M.: Diel patterns in coastal-stream nitrate concentrations linked to evapotranspiration in the riparian zone of a low-relief, agricultural catchment, Hydrol. Process., 28, 2150-2158, doi:10.1002/hyp.9763, 2014.

Gassmann, M., Lange, J., and Schuetz, T.: Erosion modelling designed for water quality simulation, Ecohydrology, 5.3, 269-278, doi:10.1002/eco.207, 2011.
Genereux, D.: Quantifying uncertainty in tracer-based hydrograph separations, Water Resour. Res., 34, 915-919, doi:10.1029/98wr00010, 1998.

Guan, K., Thompson, S. E., Harman, C. J., Basu, N. B., Rao, P. S. C., Sivapalan, M., Packman, A. I., and Kalita, P. K.: Spatiotemporal scaling of hydrological and agrochemical export dynamics in a tile-drained Midwestern watershed, Water Resour. Res., 47, W00J02, doi:10.1029/2010wr009997, 2011.

Haggerty, R., Ribot, M., Singer, G. A., Martí, E., Argerich, A., Agell, G., and Battin, T. J.: Ecosystem respiration increases with biofilm growth and bedforms: Flume measurements with resazurin, J. Geophys. Res.-Biogeo., 119, 2220 2230, doi:10.1002/2013JG002498, 2014.

Hall, R. J. O. and Tank, J. L.: Ecosystem metabolism controls nitrogen uptake in streams in Grand Teton National Park, Wyoming, Limnol. Oceanogr., 48, 1120-1128, doi:10.4319/lo.2003.48.3.1120, 2003.

Harvey, J. W., Böhlke, J. K., Voytek, M. A., Scott, D., and Tobias, C. R.: Hyporheic zone denitrification: Controls on effective reaction depth and contribution to whole-stream mass balance, Water Resour. Res., 49, 6298-6316, doi:10.1002/wrcr.20492, 2013.

Hensley, R. T., Cohen, M. J., and Korhnak, L. V.: Hydraulic effects on nitrogen removal in a tidal spring-fed river, Water Resour Res., 51.3, 1443-1456, doi:10.1002/2014WR016178, 2015.

Hill, A. R.: Nitrate Removal in Stream Riparian Zones, J. Environ. Qual., 25, 743-755, doi:10.2134/jeq1996.00472425002500040014x, 1996.

Howarth, R. W., Billen, G., Swaney, D., Townsend, A., Jaworski, N., Lajtha, K., Downing, J. A., Elmgren, R., Caraco, N., Jordan, T., Berendse, F., Freney, J., Kudeyarov, V., Murdoch, P., and Zhao-Liang, Z.: Regional nitrogen budgets and riverine N \& P fluxes for the drainages to the North Atlantic Ocean: Natural and human influences, Biogeochemistry, 35, 75-139, doi:10.1007/978-94-009-1776-7, 1996.

Huang, H., Chen, D., Zhang, B., Zeng, L., and Dahlgren, R. A.: Modeling and forecasting riverine dissolved inorganic nitrogen export using anthropogenic nitrogen inputs, hydroclimate, and land-use change, J. Hydrol., 517, 95-104, doi:10.1016/j.jhydrol.2014.05.024, 2014.

Hunsaker, C. T. and Levine, D. A.: Hierarchical Approaches to the Study of Water Quality in Rivers, Bioscience, 45, 193-203, doi:10.2307/1312558, 1995.

Isaak, D. J., Peterson, E. E., Ver Hoef, J. M., Wenger, S. J., Falke, J. A., Torgersen, C. E., Sowder, C., Steel, E. A., Fortin, M.-J., Jordan, C. E., Ruesch, A. S., Som, N., and Monestiez, P.: Applications of spatial statistical network models to stream data, Wiley Interdiscip. Rev. Water, 1, 277-294, doi:10.1002/wat2.1023, 2014.

Johnes, P. J.: Evaluation and management of the impact of land use change on the nitrogen and phosphorus load delivered to surface waters: the export coefficient modelling approach, J. Hydrol., 183, 323-349, doi:10.1016/0022-1694(95)02951-6, 1996.

Kiel, B. A. and Cardenas, B. M.: Lateral hyporheic exchange throughout the Mississippi River network, Nat. Geosci., 7, 413417, doi:10.1038/ngeo2157, 2014.

Krause, S., Blume, T., and Cassidy, N. J.: Investigating patterns and controls of groundwater up-welling in a lowland river by combining Fibre-optic Distributed Temperature Sensing with obser- 
vations of vertical hydraulic gradients, Hydrol. Earth Syst. Sci., 16, 1775-1792, doi:10.5194/hess-16-1775-2012, 2012.

Lam, Q. D., Schmalz, B., and Fohrer, N.: Assessing the spatial and temporal variations of water quality in lowland areas, Northern Germany, J. Hydrol., 438-439, 137-147, doi:10.1016/j.jhydrol.2012.03.011, 2012.

Lewandowski, J. and Nützmann, G.: Nutrient retention and release in a floodplain's aquifer and in the hyporheic zone of a lowland river, Ecol. Eng., 36, 1156-1166, doi:10.1016/j.ecoleng.2010.01.005, 2010.

Likens, G. E. and Bormann, F. H.: Linkages between terrestrial and aquatic ecosystems, Bioscience, 24, 447-456, 1974.

Lomas, M. W. and Glibert, P. M.: Temperature regulation of nitrate uptake: A novel hypothesis about nitrate uptake and reduction in cool-water diatoms, Limnol. Oceanogr., 44, 556-572, doi:10.4319/lo.1999.44.3.0556, 1999.

Luft, G., Morgenschweis, G., and Vogelbacher, A.: Influence of large-scale changes of relief on runoff characteristics and their consequences for flood-control design, in: Scientific procedures applied to the planning, design and management of water resources systems, edited by: Plate, E. and Buras, N., Hamburg, 1985.

Mallard, J., McGlynn, B. and Covino, T.: Lateral inflows, streamgroundwater exchange, and network geometry influence stream water composition, Water Resour. Res., 50.6, 4603-4623, doi:10.1002/2013wr014944, 2014.

Marwick, T. R., Tamooh, F., Ogwoka, B., Teodoru, C., Borges, A. V., Darchambeau, F., and Bouillon, S.: Dynamic seasonal nitrogen cycling in response to anthropogenic $\mathrm{N}$ loading in a tropical catchment, Athi-Galana-Sabaki River, Kenya, Biogeosciences, 11, 443-460, doi:10.5194/bg-11-443-2014, 2014.

McCarty, G. W., Hapeman, C. J., Rice, C. P., Hively, W. D., McConnell, L. L., Sadeghi, A. M., Lang, M. W., Whitall, D. R., Bialek, K. and Downey, P.: Metolachlor metabolite (MESA) reveals agricultural nitrate-N fate and transport in Choptank River watershed, Sci. Total Environ., 473-474, 473-482, doi:10.1016/j.scitotenv.2013.12.017, 2014.

Mitchell, M. J., Driscoll, C. T., Kahl, J. S., Murdoch, P. S., and Pardo, L. H.: Climatic Control of Nitrate Loss from Forested Watersheds in the Northeast United States, Environ. Sci. Technol., 30, 2609-2612, doi:10.1021/es9600237, 1996.

Molenat, J., Gascuel-Odoux, C., Ruiz, L., and Gruau, G.: Role of water table dynamics on stream nitrate export and concentration in agricultural headwater catchment (France), J. Hydrol., 348, 363-378, doi:10.1016/j.jhydrol.2007.10.005, 2008.

Montreuil, O., Merot, P., and Marmonier, P.: Estimation of nitrate removal by riparian wetlands and streams in agricultural catchments: effect of discharge and stream order, Freshw. Biol., 55, 2305-2318, doi:10.1111/j.1365-2427.2010.02439.x, 2010.

Moore, I. D. and Foster, G. R.: Hydraulics and overland flow, in: Process studies in hillslope hydrology, Vol. 539, edited by: Anderson, M. G. and Burt, T. P., Wiley, Chichester, 1990.

Moore, R. D.: Slug injection using salt in solution, in: Streamline Watershed Management Bulletin 8.2, 1-6, 2005.

Mulholland, P. J., Helton, A. M., Poole, G. C., Hall, R. O., Hamilton, S. K., Peterson, B. J., Tank, J. L., Ashkenas, L. R., Cooper, L. W., Dahm, C. N., Dodds, W. K., Findlay, S. E. G., Gregory, S. V, Grimm, N. B., Johnson, S. L., McDowell, W. H., Meyer, J. L., Valett, H. M., Webster, J. R., Arango, C. P., Beaulieu, J.
J., Bernot, M. J., Burgin, A. J., Crenshaw, C. L., Johnson, L. T., Niederlehner, B. R., O'Brien, J. M., Potter, J. D., Sheibley, R. W., Sobota, D. J., and Thomas, S. M.: Stream denitrification across biomes and its response to anthropogenic nitrate loading, Nature, 452, 202-205, 2008.

Payn, R. A., Gooseff, M. N., McGlynn, B. L., Bencala, K. E., and Wondzell, S. M.: Exploring changes in the spatial distribution of stream baseflow generation during a seasonal recession, Water Resour. Res., 48, W04519, doi:10.1029/2011wr011552, 2012.

Poff, N., Bledsoe, B., and Cuhaciyan, C.: Hydrologic variation with land use across the contiguous United States: geomorphic and ecological consequences for stream ecosystems, Geomorphology, 79, 264-285, doi:10.1016/j.geomorph.2006.06.032, 2006.

Ranalli, A. J. and Macalady, D. L.: The importance of the riparian zone and in-stream processes in nitrate attenuation in undisturbed and agricultural watersheds-A review of the scientific literature, J. Hydrol., 389, 406-415, 2010.

Ruiz, L., Abiven, S., Martin, C., Durand, P., Beaujouan, V., and Molénat, J.: Effect on nitrate concentration in stream water of agricultural practices in small catchments in Brittany: II. Temporal variations and mixing processes, Hydrol. Earth Syst. Sci., 6, 507-514, doi:10.5194/hess-6-507-2002, 2002.

Schilling, K. E., Li, Z., and Zhang, Y.-K.: Groundwatersurface water interaction in the riparian zone of an incised channel, Walnut Creek, Iowa, J. Hydrol., 327, 140-150, doi:10.1016/j.jhydrol.2005.11.014, 2006.

Schilling, K. and Zhang, Y.-K.: Baseflow contribution to nitratenitrogen export from a large, agricultural watershed, USA, J. Hydrol., 295, 305-316, doi:10.1016/j.jhydrol.2004.03.010, 2004.

Schneider, V. R. and Arcement, G. J.: Guide for Selecting Manning's Roughness Coefficients for Natural Channels and Flood Plains, Water-Supply Paper 2339, available from the US Geological Survey, Books and Open-File Reports Section, Federal Center, Denver, CO, 1989.

Schuetz, T. and Weiler, M.: Quantification of localized groundwater inflow into streams using ground-based infrared thermography, Geophys. Res. Lett., 38, L03401, doi:10.1029/2010g1046198, 2011.

Smethurst, P. J., Petrone, K. C., Langergraber, G., Baillie, C. C., Worledge, D., and Nash, D.: Nitrate dynamics in a rural headwater catchment: measurements and modelling, Hydrol. Process., 28, 1820-1834, doi:10.1002/hyp.9709, 2014.

Stream Solute Workshop: Concepts and Methods for Assessing Solute Dynamics in Stream Ecosystems, J. N. Am. Benthol. Soc., 9, 95-119, doi:10.2307/1467445, 1990.

Tesoriero, A. J., Duff, J. H., Saad, D. A., Spahr, N. E., and Wolock, D. M.: Vulnerability of Streams to Legacy Nitrate Sources, Environ. Sci. Technol., 47, 3623-3629, doi:10.1021/es305026x, 2013.

Thompson, S. E., Basu, N. B., Lascurain Jr., J., Aubeneau, A., and Rao, P. S. C.: Relative dominance of hydrologic versus biogeochemical factors on solute export across impact gradients, Water Resour. Res., 47, W00J05, doi:10.1029/2010wr009605, 2011.

Triska, F. J., Kennedy, V. C., Avanzino, R. J., Zellweger, G. W., and Bencala, K. E.: Retention and transport of nutrients in a thirdorder stream in northwestern California: hyporheic processes, Ecology, 1893-1905, 1989.

Vogt, E., Braban, C. F., Dragosits, U., Durand, P., Sutton, M. A., Theobald, M. R., Rees, R. M., McDonald, C., Mur- 
ray, S., and Billett, M. F.: Catchment land use effects on fluxes and concentrations of organic and inorganic nitrogen in streams, Agr. Ecosyst. Environ., 199, 320-332, doi:10.1016/j.agee.2014.10.010, 2015.

Wagenschein, D. and Rode, M.: Modelling the impact of river morphology on nitrogen retention - A case study of the Weisse Elster River (Germany), Ecol. Modell., 211, 224-232, doi:10.1016/j.ecolmodel.2007.09.009, 2008.

Windolf, J., Thodsen, H., Troldborg, L., Larsen, S. E., Bøgestrand, J., Ovesen, N. B., and Kronvang, B.: A distributed modelling system for simulation of monthly runoff and nitrogen sources, loads and sinks for ungauged catchments in Denmark, J. Environ. Monit., 13, 2645-2658, doi:10.1039/c1em10139k, 2011.

Wriedt, G. and Rode, M.: Modelling nitrate transport and turnover in a lowland catchment system, J. Hydrol., 328, 157-176, doi:10.1016/j.jhydrol.2005.12.017, 2006.
Wriedt, G., Spindler, J., Neef, T., Meißner, R., and Rode, M.: Groundwater dynamics and channel activity as major controls of in-stream nitrate concentrations in a lowland catchment system?, J. Hydrol., 343, 154-168, doi:10.1016/j.jhydrol.2007.06.010, 2007.

Zarnetske, J. P., Haggerty, R., Wondzell, S. M., and Baker, M. A.: Dynamics of nitrate production and removal as a function of residence time in the hyporheic zone, J. Geophys. Res., 116, G01025, doi:10.1029/2010JG001356, 2011.

Zarnetske, J. P., Haggerty, R., Wondzell, S. M., Bokil, V. A., and González-Pinzón, R.: Coupled transport and reaction kinetics control the nitrate source-sink function of hyporheic zones, Water Resour. Res., 48, W11508, doi:10.1029/2012wr011894, 2012. 